\title{
ФОРМУВАННЯ «ЕКСЦЕНТРИЧНОӦ» ПОЕТИКИ АВАНГАРДИСТСЬКОГО ТЕАТРУ: «БИК НА ДАХУ» ЖАНА КОКТО - ДАРЬЮСА МІЙО
}

\author{
Наталія Владимирова ${ }^{1 a}$, Марина Гринишина ${ }^{2 b}$ \\ 1 доктор мистецтвознавства, професор; e-mail: super-parus64@ukr.net; ORCID: 0000-0001-8882-3957 \\ ${ }^{2}$ доктор мистецтвознавства, с. н. c.; e-mail: marina.grinishina@gmail.com; ORCID: 0000-0002-6010-2282 \\ а Київський національний університет театру, кіно і телебачення ім. І. К. Карпенка-Карого, Київ, Україна

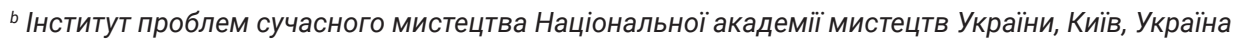

\begin{abstract}
Анотація
Мета статті - поглибити дослідження авангардистської театральної культури 1920-х рр., зосередившись на проблемі формування ії «ексцентричної» поетики. Матеріалом досліду послугувала творчість Жана Кокто - одного з проводирів європейської «художньої революції» першої третини XX ст., зокрема його пантоміма «Бик на даху» на музику члена групи «Шість» Дарьюса Мійо (1920), що продовжила експерименти митця з «кабаретизації» французької сцени. Методологію дослідження склала комбінація елементів історико-культурного, історикореконструктивного та структурно-аналітичного методів. Наукова новизна полягає у введенні в український театрознавчий обіг висвітлення та аналізу творчих надбань Ж. Кокто у сфері французького музично-драматичного театру початку 20-х років XX ст. Висновки. Процес формування «ексцентричної» поетики, або так звана «кабаретизація» європейського та радянського кону 1920-х рр., став яскравою прикметою авангардистської театральної культури. Це був один із перших провокативних сценаріїв кардинального оновлення театру та важливий етап загального культурного поступу. Пошук різноманітних способів збагачення сценічної лексики є актуальним питанням сучасного театрального процесу. Тож різнорівневий аналіз «переломних» періодів історії культури, коли народжувалася нова естетика, залишається одним із найрезультативніших методів динамізації відповідних процесів сьогодення.
\end{abstract}

Ключові слова: Жан Кокто; Дарьюс Мійо; театральний авангард; поетика; ексцентризм; цирк; пантоміма; жанрова еволюція; стилізація

\section{Аналіз останніх досліджень і публікацій. Постановка проблеми}

Театральний авангард став предметом дослідження українського театрознавства порівняно недавно. Уведені на сьогодні у вітчизняний науковий обіг повноформатні праці - це монографії Г. Веселовської «Український театральний авангард» (2010), де викладено окремі сторінки його вітчизняної історії, та О. Клековкіна «Mise en Scene: Ідеї. Концепції. Напрями» (2017), де презентовано творчі пошуки відповідного спрямування європейських (зокрема Л. Йєсснера, А. Арто), російських (Всеволода 
Меєргольда) та українських (Леся Курбаса) режисерів. Заслуговує на увагу також збірник «Українські авангардисти як теоретики і публіцисти» (Горбачов, Папета, та Папета упоряд., 2005), де презентовано концепції О. Богомазова, О. Екстер, А. Петрицького - митців, причетних до становлення української авангардистської сценографії. Утім, «переломна» епоха в історії культури, багата на мистецькі прецеденти, непересічні творчі особистості й неординарні явища, потребує, звичайно, більш різноформатного системного аналізу та багатоаспектного вивчення.

Мета статті - поглибити дослідження авангардистської театральної культури 1920-х рр., зосередившись зокрема на проблемі формування іiї «ексцентричної» поетики. За матеріал взято творчість Жана Кокто - одного з проводирів європейської «художньої революції» першої третини XX ст., зокрема його пантоміму «Бик на даху» на музику члена групи «Шість» Дарьюса Мійо, що продовжила експерименти митця з «кабаретизації» французької сцени. Методологією дослідження стала комбінація історико-культурного методу, історико-реконструктивного та структурно-аналітичного, що уможливило багаторівневий аналіз складного «переломного» періоду історії мистецтва та сприяло об'єктивнішому погляду на місце і роль його окремих явищ у загальному художньому поступі.

\section{Виклад основного матеріалу}

1920-ті рр. за визнаною періодизацією історії європейської культури - це епоха «художньої революції», яку один з їі французьких проводирів - поет, драматург, художник, хореограф, кінорежисер - Жан Кокто (1985, с.63) визначив так:

«Революція ця відбувалася за обставин надзвичайно цікавих, у самий розпал війни 1914 року, війни настільки незвичної, що кожен із нас, мобілізованих, безперешкодно пересувався з одного “фронту”, в Парижі, на інший, на фронт військових дій [...] Ця революція відбулася майже непомітно, і коли усі, хто мав підстави страхатися її, нарешті зрозуміли у чому справа, боротися із нею було вже запізно. Ми скористалися з того, що місто майже спорожніло, воно тільки й чекало, аби його взяли, і ми завоювали міцні позиції [...]».

Черговий рух художнього оновлення звично супроводжувався гучною відмовою його учасників від традиційних мистецьких форм і відпрацьованих технологій. Проте нинішня ситуація відзначалася й відмітною рисою - окрім іншого, авангардисти закликали майбутнього читача - слухача - глядача разом з ними «весело попрощатися з минулим». «Епоха 20-х років минулого століття, - слушно зауважила російський філолог С. Дубровіна (2002, с.90), - це золотий вік клоунади, коли намагання епатувати буржуазну публіку й звільнити мистецтво від застарілих догм призвело повсюдно до царювання гри, ілюзії, сплеску яскравих клоунських фарб [...] Популярніший за театр, інтернаціональний (адже його мова зрозуміла усім), видовищний - цирк дозволив театру знайти у світі, що стрімко змінювався, нові форми існування». У російському та українському театрі названа тогочасною критикою (зокрема К. Державіним, С. Мокульським, П. Марковим, О. Февральським, О. Білецьким, П. Руліним, Х. Токарем, Й. Шевченком, І. Туркельтаубом, Ю. Смоли- 
чем) і теоретично обґрунтована Ю. Анненковим («Театр до кінця», 1921), С. Ейзенштейном («Монтаж атракціонів», 1923) і С. Радловим («Десять років у театрі», 1929) «циркізація - мюзикхолізація радянської сцени» тривала від 1919-го до 1929-го року. Тобто від спектаклю «Перший винокур» Л. Толстого в петроградському Ермітажному театрі до колективного «Алло, на хвилі 477!» у «Березолі».

Для європейського (зокрема французького) художнього процесу відповідного спрямування визначальним став «Парад» у постановці дягілєвського «Російського балету» 1917 р. (музика Е. Саті, лібрето Ж. Кокто, сценографія та костюми П. Пікассо, хореографія Л. М'ясіна), а продовженням - «Бик на даху» 1920 р. (музика Д. Мійо; лібрето, режисура, хореографія Ж. Кокто; сценографія та костюми Г. П. Факонне, Р. Дюфі). Програмними маніфестаціями цих експериментів слугували есе «Півень та Арлекін» (1918) і «Професійна таємниця» (1921) того ж таки Ж. Кокто. Отже, мав рацію учасник композиторської «Шістки» А. Онеггер (1979, с.166), визначивши внесок «сьомого члена» групи (яким вважав себе поет) у становлення європейського авангардизму так: «Він був живим втіленням того протесту проти усієї естетики передвоєнного часу, який кожен із нас висловлював на свій лад».

Схоже, найрезультативнішим способом оновлення різних видів мистецтва (насамперед театру та музики) французький митець вважав формування сучасного ексцентрико-комедійного "мовлення». Його звернення до "поетики "низьких" жанрів, до естетики цирку і мюзик-холу, пристрасть до ексцентріади, до незвичної й яскравої форми щонайкраще відповідало бажанню почути і відбити те незвичне й нове, що входило у повсякденність молодого століття» (Кадишев, 1985, с.6). Французькі композитори-початківці з групи «Шість» виявилися найпалкішими прихильниками художніх інновацій Ж. Кокто, навзаєм він став інспіратором і пропагандистом їхньої творчості.

«Культивувати комічне» Ж. Кокто почав із того, що «[...] близько 1920 року [...] проголосив необхідність створення пародійної музики [...]» (Онеггер, 1979, с.176), а дещо згодом визнав, зокрема, мистецтво цирку силою, здатною оновити застарілий «реалістично-натуралістичний» французький кін: «Цирк, мюзик-хол, кінематограф [...] навіть не усвідомлюючи, що вони є спільниками, змовилися проти того, на що перетворився театр, - старого альбому з фото» (Кокто, 2000b, с.631). У першому випадку він, звісно, розраховував на творчі зусилля Е. Саті та композиторів «Шістки», у другому - справджував власні наміри, які, до речі, намагався реалізовувати ще від 1915 р. - від постановки шекспірівського «Сну літньої ночі» у паризькому цирку «Медрано». У цій виставі замість балетних вставок передбачалися циркові номери на трапеції, а клоуни (йшлося насамперед про тріо братів Фрателліні, які того сезону стали кумирами Парижа (Жандо, 1984, с.42)) мали виконувати ролі майстерників. «Такого типу вистави, що розповсюдився згодом, тоді ще не існувало», прокоментував згодом невтілений задум Ж. Кокто (цит. за: Дубровина, 2002, с.94).

Наприкінці 1919 р. митець познайомився з новим членом «Шістки», Дарьюсом Мійо, який щойно повернувся з Бразилії, де перебував на посаді секретаря посла Франції - відомого письменника Поля Клоделя. «Він привіз звідти самбу, що незабаром увійшла у моду. Проте коли він використав їі як супровід моєї пантоміми “Бик на даху” (цю назву вичитав на якійсь бразильській вивісці Клодель), яку 
Bulletin of Kyiv National University of Culture and Arts

Series in Stage Art

виконували клоуни Фрателліні, ці ритми наразі не були відомі у Франції й ледь не зчинили скандалу», - згодом напише Ж. Кокто (1985, с.98). Композитор, зі свого боку, пригадає таке: «Усе ще знаходячись під враженням від Бразилії, я створив для забави п'єсу на танцювальні мелодії танго, матчишів, самбо і португальських фадо, об'єднавши їх темою, як у формі рондо [...] Я уявив, що така музика могла би супроводжувати якийсь із фільмів Чапліна» (Мийо, 1999, с.135).

На думку дослідниці Л. Кокорєвої (1986, с.39), стійкий інтерес композитора до творчості голлівудського коміка (який цілковито поділяв Ж. Кокто) спровокував монтажну структуру матеріалу, а також - інтонаційну виразність і жорстку логіку розвитку тем «Бика на даху»: «Музика розвивається стрімко, на одному подиху, без жодних цезур, майже в єдиному, часом злегка варійованому ритмі. Мелодії танців, ніби у калейдоскопі, змінюють одна одну». Постійно присутньому на сцені Бармену відповідає тема-рефрен, що звучить п'ятнадцять разів у дванадцяти різних тональностях. 3 нею чергуються різноманітні мелодії, базовані на інтонаціях і ритмах бразильської фольклорної та авторської музики. Презентовані в сюїті образи та настрої умовно розподіляються між трьома емоційно-смисловими сферами, зіставними з кінематографічними епізодами конкретного змісту: енергійно танцювальною (з погонею, бійкою, колотнечею), ліричною (з утрируваночуттєвою характеристикою манірних героїнь і гротескними сценами кохання), бравурно-войовничою (з талановитими й сміливими героями популярних пригодницьких вестернів) (Головіна, 2017). До того ж для її виконання достатньо було камерного колективу - у «Театрі Єлисейських полів» вистава йшла в супроводі невеликого оркестру Владимира Гольшмана.

За сценарієм Ж. Кокто, події пантоміми відбуваються у підпільному американському питному закладі в період дії «сухого закону». У списку дійових осіб зазначено Бармена, Полісмена, відвідувачів бару: Боксера, який, граючи на більярді, картинно підіймає ногу, цілячись, як на американських літографіях; чорношкірого Карлика; Елегантну мадам у червоному - трохи вульгарну даму півсвіту; Руду даму - грубувату емансипе в чоловічому костюмі; Букмекера з усмішкою, що сяє золотими зубами; Пана у фраку (Кокто, 2000а, с.89). На слушну думку одного з сучасних балетознавців, їхніми прототипами «стали близькі героям Чапліна фарсові типажі сучасності» початку XX ст. (Головіна, 2017). У виставі вони розважалися, танцювали, вживали алкогольні напої та коктейлі, грали на більярді й у кості. Костями, до речі, слугували картонні коробки, що оберталися довкола своєї осі, а дошку створювали «голови» Пана у фраку, Букмекера та Бармена, який ховався за «газетою з літерами, як на афіші». У розпал веселощів до бару раптово входив Полісмен. Тоді стакани та фужери миттю порожніли, Бармен одним рухом прибирав пляшки, виставляв на їхнє місце табличку «Жодного алкоголю. Тільки молоко», показово струшував коктейльний шейкер і розливав по келихах відвідувачів дитячий напій. Ті, зі свого боку, старанно зображували тверезих і розігрували пасторальну сценку, удавано насолоджуючись молоком. Полісмен підхоплював загальний настрій - ніжно всміхаючись, витанцьовував меланхолійний вальс. Коли він сідав за стійку, Бармен натискав тривожну кнопку, але замість звуків сирени під стелею вмикався вентилятор, що, опустившись донизу, лопат- 
тю відрізав голову вартового порядку. Господар закладу спритно віддавав її Рудій дамі, яка, ніби Саломея зі скульптурної композиції Руанського собору (Мийо, 1999, с.136), затискала голову ногами й пускалася в танок на руках. Заклад поступово порожнів, Бармен, залишившись на самоті, пришивав Полісмену голову, той оживав й отримував від свого вбивці «триметровий рахунок».

Двадцятихвилинна вистава, прем'єра якої відбулася 21 лютого 1920 р. у «Театрі Єлисейських полів», «йшла недовго, проте мала величезний успіх» у паризької публіки (Жандо, 1984, с.42). Загалом «Бик на даху» розвивав художню ідею «ірраціонального реалізму», уперше презентовану Ж. Кокто у «Параді» - утрирувано-реалістичні (фарсові) елементи знову комбінувалися з нереалістичними (абсурдистськими). Зазначений прийом було унаочнено в зовнішньому вигляді персонажів, чиї вбрані у звичайні вечірні сукні та костюми або в уніформу тіла увінчували величезні голови з пап'є-маше. Увиразнювався він і в хореографії, де балетні па і дансингові елементи рядували з акробатичними трюками тріо братів Фрателліні, і де Ж. Кокто час від часу використовував «кінематографічний прийом уповільнених рухів» (Парнах, 1922, с.24).

«Бик на даху» входив до програми вечора разом із «Трьома маленькими п'єсами» Е. Саті, «Фокстротом» Ж. Оріка та «Кокардами» Ф. Пуленка. Д. Мійо (1999, с.136) зазначив:

«Цювиставукритикатапубліка сприйнялаякдемонструваннянашоїестетики. Веселий спектакль під егідою Саті, прозваного у газетах “містифікатором", символізував для публіки демонстрацію естетики мюзикхолу й цирку, а для критики став зразком післявоєнної музики. [...] мене охрестили музикантом ярмарку і балагану - мене, який ненавидів балаганну музику. Вигадуючи “Бика на даху”, я просто хотів створити веселий, без усіляких претензій дивертисмент на згадку про бразильські ритми, що полонили мене і, мій Боже! ніколи мене не смішили».

Натомість Ж. Кокто скандальний «присмак» його першої самостійної сценічної роботи не тільки не збентежив, а, навпаки, упевнив у правильності обраного напряму мистецького руху. Підтвердженням цього стала наступна пантоміма режисера на музику композиторів «Шістки» - «Молодята на Ейфелевій вежі» (1921).

Наукова новизна дослідження полягає у введенні в український театрознавчий обіг висвітлення та аналізу творчих надбань Ж. Кокто у сфері французького музично-драматичного театру початку 20-х років XX століття.

\section{Висновки}

Процес формування «ексцентричної» поетики, або так звана «кабаретизація» європейського та радянського кону 1920-х рр., став яскравою прикметою авангардистської театральної культури. Це був один із перших провокативних сценаріїв кардинального оновлення театру та важливий етап загального культурного поступу.

Художні інновації Ж. Кокто 1920-х рр. із синтезу різних стилів і жанрів (класичного балету, естрадного ревю, циркового мистецтва, спортивної акробатики) акумулю- 
вали водночас протест митця проти минулої естетики французької сцени та його бачення майбутньої художньої реальності, що й увиразнила пантоміма «Бик на даху» на музику Д. Мійо.

Пошук різноманітних способів збагачення сценічної лексики залишається актуальним питанням сучасного театрального мистецтва. Тож різнорівневий аналіз «переломних» періодів історії культури, коли народжується нова естетика, є одним із найрезультативніших методів динамізації відповідних процесів сьогодення.

\section{СПИСОК ПОСИЛАНЬ}

Веселовська, Г., 2010. Український театральний авангард. Київ: Фенікс.

Головина, Н., 2017. Балеты Д. Мийо в диалоге с «седьмым искусством». Вестник Академии русского балета им. А. Я. Вагановой, [online] 4. Доступно: <https://vaganov.elpub.ru/jour/ article/view/442/0> [Дата звернення 10 квітня 2020].

Горбачов, Д., Папета, О. та Папета, С., упоряд., 2005. Українські авангардисти як теоретики і публіцисти. Київ: Тріумф.

Дубровина, С., 2002. Комическое начало в драматургии Жана Кокто. Вопросы филологии, 2 (11), с.90-100.

Жандо, Д., 1984. История мирового цирка. Перевод: М. Кобрина. Москва: Искусство.

Кадышев, В., 1985. О Жане Кокто. В: Ж. Кокто. Портреты-воспоминания. Перевод: В. Кадышев. Москва: Известия.

Клековкін, О., 2017. Mise en Scene: Ідеї. Концепції. Напрями. Київ: Фенікс.

Кокорева, Л., 1986. Дариус Мийо: Жизнь и творчество. Москва: Советский композитор.

Кокто, Ж., 1985. Портреты-воспоминания. Перевод: В. Кадышев. Москва: Известия.

Кокто, Ж., 2000а. Петух и Арлекин: Либретто. Воспоминания. Статьи о музыке и театре. Перевод: М. Сапонов. Москва: Прест.

Кокто, Ж., 2000b. Профессиональная тайна. В: Петух и Арлекин. Перевод: А. Цывьян. СанктПетербург: Кристалл.

Мийо, Д., 1999. Моя счастливая жизнь. Перевод: Л. Кокорева. Москва: Композитор.

Онеггер, А., 1979. О музыкальном искусстве. Перевод: В. Александрова, В. Быков. Ленинград: Музыка.

Парнах, В., 1922. Пантомима, балет, цирк в Париже. Вещь, 1-2.

\section{REFERENCES}

Dubrovina, S., 2002. Komicheskoe nachalo v dramaturgii Zhana Kokto [A comic start in the drama of Jean Cocteau]. Voprosy filologii, 2 (11), pp.90-100.

Golovina, N., 2017. Balety D. Miio v dialoge s "sedmym iskusstvom". Vestnik Akademii russkogo baleta im. A. la. Vaganovoi, [online] 4. Available at: <https://vaganov.elpub.ru/jour/article/ view/442/0> [Accessed 10 April 2020].

Horbachov, D., Papeta, O. ta Papeta, S., eds., 2005. Ukrainski avanhardysty yak teoretyky i publitsysty [Ukrainian avant-garde as theoreticians and publicists]. Kyiv: Triumf.

Kadyshev, V., 1985. O Zhane Kokto [About Jean Cocteau]. In: Zh. Kokto. Portrety-vospominaniia [Portraits-memories]. Translation: V. Kadyshev. Moscow: Izvestiia. 
Klekovkin, O., 2017. Mise en Scene: Idei. Kontseptsii. Napriamy [Mise en Scene: Ideas. Concepts. Directions]. Kyiv: Feniks.

Kokoreva, L., 1986. Darius Miio: Zhizn i tvorchestvo [Darius Millau: Life and work]. Moscow: Sovetskii kompozitor.

Kokto, Zh., 1985. Portrety-vospominaniia [Portraits-memories]. Translation: V. Kadyshev. Moscow: Izvestiia.

Kokto, Zh., 2000. Petukh i Arlekin: Libretto. Vospominaniia. Stati o muzyke i teatre [Rooster and Harlequin: Libretto. Memories. Articles about music and theater]. Translation: M. Saponov. Moscow: Prest.

Kokto, Zh., 2000. Professionalnaia taina [Professional Secret]. In: Petukh i Arlekin [Rooster and Harlequin]. Translation: A. Tsyvyan. St. Petersburg: Kristall.

Miio, D., 1999. Moia schastlivaia zhizn [My happy life]. Translation: L. Kokoreva. Moscow: Kompozitor. Onegger, A., 1979. O muzykalnom iskusstve [On the musical art]. Translation: V. Alexandrova, V. Bykov. Leningrad: Muzyka.

Parnakh, V., 1922. Pantomima, balet, tcirk v Parizhe [Pantomime, ballet, circus in Paris]. Veshch, 1-2.

Veselovska, H., 2010. Ukrainskyi teatralnyi avanhard [Ukrainian theatrical avant-garde]. Kyiv: Feniks. Zhando, D., 1984. Istoriia mirovogo tcirka [The history of the world circus]. Translation: M. Kobrin. Moscow: Iskusstvo.

\title{
ФОРМИРОВАНИЕ «ЭКСЦЕНТРИЧЕСКОЙ» ПОЭТИКИ
} АВАНГАРДИСТСКОГО ТЕАТРА: «БЫК НА КРЫШЕ» ЖАНА КОКТО - ДАРЬЮСА МИЙО

\author{
Наталья Владимирова ${ }^{1 a}$, Марина Гринишина \\ ${ }^{1}$ доктор искусствоведения, профессор; e-mail: super-parus64@ukr.net; ORCID: 0000-0001-8882-3957 \\ ${ }^{2}$ доктор искусствоведения, с. н. c.; e-mail: marina.grinishina@gmail.com; ORCID: 0000-0002-6010-2282

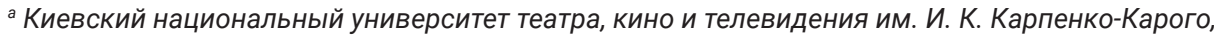 \\ Киев, Украина \\ ${ }^{\mathrm{b}}$ Институт проблем современного искусства Национальной академии искусств Украины, \\ Киев, Украина
}

\section{Аннотация}

Цель статьи - углубить исследование авангардистской театральной культуры 1920-х гг., сосредоточившись на проблеме формирования ее «эксцентрической» поэтики. Материалом исследования послужило творчество Жана Кокто - одного из лидеров европейской "художественной революции» первой трети XX века, в частности его пантомима «Бык на крыше» на музыку члена группы «Шесть» Дарьюса Мийо (1920), которая продолжила эксперименты художника по «кабаретизации» французской сцены. Методологию исследования составила комбинация элементов историко-культурного, историко-реконструктивного и структурно-аналитического методов. Научная новизна заключается во введении в украинский театроведческий обиход анализа творческих 
достижений Ж. Кокто во французском музыкально-драматическом театре начала 20-х гг. XX в. Выводы. Процесс формирования «эксцентрической» поэтики, или так называемая «кабаретизация» европейских и советских подмостков 1920-х гг., стал яркой приметой авангардистской театральной культуры. Это был один из первых провокационных сценариев обновления театра и важный этап общекультурного прогресса. Поиск разнообразных способов обогащения сценической лексики - актуальный вопрос современного театрального искусства. Поэтому многоуровневый анализ «переломных» периодов истории культуры, порождавших новую эстетику, остается одним из наиболее результативных методов динамизации соответствующих сегодняшних процессов.

Ключові слова: Жан Кокто; Дарьюс Мийо; театральный авангард; поэтика; эксцентризм; цирк; пантомима; жанровая эволюция; стилизация

\title{
FORMING OF THE "ECCENTRIC" POETICS OF THE VANGUARD THEATRE: "BULL ON THE ROOF" BY JEAN COCTEAU - DARIUS MILHAUD
}

\author{
Nataly Vladimirova ${ }^{1 a}$, Marina Grynyshyna ${ }^{2 b}$ \\ 1 Doctor in Art Studies, Professor; e-mail: super-parus64@ukr.net; ORCID: 0000-0001-8882-3957 \\ ${ }^{2}$ Doctor in Art Studies, Senior Researcher; e-mail: marina.grinishina@gmail.com; ORCID: 0000-0002-6010-2282 \\ ${ }^{a}$ K. Karpenko-Kary Kyiv National Theatre, Cinema \& Television University, Kyiv, Ukraine \\ ${ }^{b}$ National Academy of Art of Ukraine Modern Art Research Institute, Kyiv, Ukraine
}

\begin{abstract}
Purpose of the study is to deep the research of the $1920^{\text {th }}$ vanguard theatrical culture, concentrating on the problem of its "eccentric" poetics' forming. The study is based on the creative activity by Jean Cocteau - one of the leaders of the first third of the $20^{\text {th }}$ century "artistic revolution", in particular, on his pantomime "Bull on the Roof" with the music of the "Six" member Darius Milhaud (1920), which was the next artist's experiment for the French stage "cabaretization".

The methodology of the study combines the elements of the historical-cultural, historicalreconstructive and structural-analytic methods. Scientific novelty of the study lies in the lighting up of the points, which were insufficiently investigated by the native theatrical science, and in bringing into Ukrainian theatrical researches general use Jean Cocteau creative achievements in the French decade beginning music- \&-dramatic theatre. Conclusions. Forming of the "eccentric" poetics process, or so called "cabaretization" of the European and Soviet stage in $1920^{\text {th }}$, became an evident token of the vanguard theatrical culture. It was one of the first provocative plots of the theatre innovation and an important step of the general cultural advancement. Searching the different ways to enrich the stage vocabulary is an actual question of the contemporary theatre. Therefore a different-level analysis of the history of culture "turning points", when the new esthetics is born, leaves one of the most resultative methods to precipitate the today's corresponding process.
\end{abstract}

Keywords: Jean Cocteau; Darius Milhaud; theatrical vanguard; poetics; eccentrics; circus; pantomime; evolution of genres; stylization 